\title{
Lífsstíll verður ferðavara; próun fyrirtækja í hestamennsku á Íslandi
}

\author{
Ingibjörg Sigurðardóttir ${ }^{1}$
}

\begin{abstract}
Ágrip
Í pessari grein er skoðað hvað einkenni próun fyrirtækja í hestamennsku (e. horse industry) á Íslandi og hverjar séu helstu ástæður pess að hestamennska sem áhugamál eða lífsstíll er próuð yfir í fyrirtæki. Auk pess er rýnt í pað hver sé páttur ferðapjónustu í próun hestamennsku sem atvinnugreinar á Íslandi. Skoðað er hvernig hestamennska og ferðamennska mætast í fjölpættri og ört vaxandi atvinnustarfsemi, ekki síst í dreifbýli. Talsverðar rannsóknir eru til um einkenni og próun lífsstílsfyrirtækja m.a. í ferðapjónustu en lítið er um rannsóknir meðal slíkra fyrirtækja í hestamennsku. Rannsóknin var eigindleg og framkvæmd í gegnum hálfopin viðtöl við 16 rekstraraðila í hestamennsku. Vísbendingar komu fram um að fyrirtæki í hestamennsku gangi fremur milli kynslóða en ferðapjónustufyrirtæki almennt, sem kemur nokkuð á óvart og vekur athygli á mögulegri sérstöðu hestamennsku og hestatengdrar ferðapjónustu samanborið við önnur form ferðapjónustu. Tengsl hestamennsku og ferðapjónustu eru fjölpætt og spanna allt frá pví að fyrirtæki í hestamennsku hafi tekjur sínar eingöngu af ferðapjónustu yfir í að fyrirtækin hafi engin bein tengsl við ferðapjónustu. Leitt er líkum að pví að í peim fyrirtækjum par sem ferðapjónusta hefur ekki bein áhrif innan fyrirtækjanna sjálfra hafi ferðalög tengd peim töluverð óbein efnahagsleg áhrif innan ferðapjónustunnar.
\end{abstract}

\begin{abstract}
This paper deals with what identifies the development of equestrian businesses in Iceland and why the lifestyle and hobby of the equestrian business operators was developed into a business or profession. The importance of tourism in this development is also analysed. The paper looks into how the horse industry and the tourism industry are intertwined in a thriving industry of equestrian tourism in Iceland, particularly in rural areas. The research was qualitative and conducted through open ended interviews with 16 operators within the horse industry in Iceland. The findings indicate that it is more likely that horse based businesses, including horse tourism businesses, are to be passed forward to new generations of operators than tourism businesses in general. Relations of the horse industry in one hand and the tourism industry on the other seem to be important. Businesses combining tourism and different kinds of horse based activities seem to be common. The combination varies from horse businesses with no direct relations to tourism to businesses entirely basing their income
\end{abstract}

${ }^{1}$ Höfundur er lektor við Ferðamáladeild Háskólans á Hólum. Netfang: inga@holar.is. Ritrýnum og ritstjóra eru færðar pakkir fyrir uppbyggilega rýni og gagnlegar ábendingar við ritun og frágang greinarinnar.

This work is licensed under a Creative Commons Attribution 4.0 License. 
on tourism. It is however concluded that activities related to horse based businesses not offering tourism services do increase tourism in Iceland in an indirect way.

JEL flokkun: O13, Z32

Lykilorð: Áhugamál, lífsstíll, hestamennska, hestaferðapjónusta, dreifbýli, kynslóðaskipti

\section{Inngangur}

Hestamennska (e. horsemanship) hefur verið skilgreind sem samband manns og hests. Hestamennska á sér langa sögu og birtist með mismunandi hætti í menningu, sögu og atvinnulífi pjóða (Helgadóttir, 2006). Enska hugtakið horse industry er oft á tíðum pýtt sem hestamennska. Í peim tilfellum er gjarnan talað um „hestamennsku sem atvinnugrein“ (Helgadóttir, 2006; Sigurðardóttir og Helgadóttir, 2015b). Hestamennska sem atvinnugrein (e. horse industry) hefur verið skilgreind sem öll starfsemi byggð á eða tengd hestum eða hestamennsku, par með talin kjarnastarfsemi eins og ræktun og pjálfun auk tengdrar starfsemi og pjónustu (The Henley Centre, 2004).

Ferðapjónusta sem byggir á hestum er hluti af hestamennsku sem atvinnugrein (Helgadóttir, 2006; Sigurðardóttir, 2015). Hestatengd ferðapjónusta hófst á Íslandi kringum 1970 og hefur próast jafnt og pétt síðan pá (Ingibjörg Sigurðardóttir, 2004). Er nú svo komið að litið er á hestaferðapjónustu á Íslandi sem fyrirmynd fyrir uppbyggingu greinarinnar erlendis (Pickel-Chevalier og Evans, 2015). Skilgreiningar á hugtökum um pessa grein ferðapjónustu eru enn nokkuð á reiki. Á ensku eru notuð hugtök eins og horse tourism, horse based tourism, equestrian tourism, equine tourism og riding tourism. Раð hvenær hvert pessara hugtaka er notað fer fremur eftir málvenju en skýrri skilgreiningu á hverju hugtaki fyrir sig (Buchmann, 2014; Sigurðardóttir, 2015). Hérlendis er að jafnaði talað um hestaferðapjónustu eða hestatengda ferðapjónustu. Eru pessi hugtök notuð sem samheiti en opinber skilgreining á peim er ekki til. Í rannsóknum Ferðamáladeildar Háskólans á Hólum á sviði hestaferðapjónustu hefur hestatengd ferðapjónusta verið skilgreind sem „hvers kyns pjónusta sem fyrirtæki eða einstaklingar veita ferðamönnum í tengslum við hesta, hvort sem um er að ræða pjónustu sem tengist reiðmönnum, hestinum sjálfum, sögu hans, ímynd, afurðum eða pætti hans í menningar- og atvinnusögu pjóðarinnar" (Ingibjörg Sigurðardóttir, 2004, bls. 6; Sigurðardóttir, 2015, bls. 151).

Pegar talað er um hestaferðapjónustu hérlendis er gjarnan verið að fjalla um stuttar og langar hestaferðir. Stuttar hestaferðir eða hestaleiga vísa til pjónustu sem getur falist í að teymt sé undir gestum í stutta stund og upp í ferðir sem taka allt að einn dag. Hestaferðir eru hins vegar skilgreindar sem pjónusta par sem gestir ferðast á hestum í meira en einn dag, pað er að gisting er innifalin í pakkanum (Lög um skipan ferðamála nr 73/2005; Sigurðardóttir og Helgadóttir, 2015a). Hestaferðapjónusta getur pó falið í sér fjölpætta aðra upplifun svo sem hestasýningar, hestaleikhús, margvíslega aðra hestatengda viðburði sem og pjónustu við aðila sem ferðast á hestum á eigin vegum (Sigurðardóttir og Helgadóttir, 2015b).

Ferðapjónusta hefur vaxið ört á Íslandi á undanförnum árum. Á árinu 2014 skapaði greinin 27,9\% gjaldeyristekna pjóðarinnar sem er hærra hlutfall af heildarútflutningi vöru og pjónustu en af sjávarafurðum annars vegar og áliðnaði hins vegar. Á sama tíma var fjöldi starfa í ferðapjónustutengdum greinum alls 21.600 (Oddný Póra Óladóttir, 2015). Milli áranna 2014 og 2015 jókst fjöldi erlendra gesta sem komu til Íslands um 29,2\% (Ferðamálastofa, 2016). Sambærilegur vöxtur á heimsvísu pað ár var 4,3\% (World Tourism Organization ONWTO, e.d.). Slíkur vöxtur í fjölda erlendra gesta skapar aukna eftirspurn eftir fjölbreyttri afpreyingu 
fyrir ferðamenn. Ef litið er til mismunandi greina innan ferðapjónustunnar hérlendis, hefur vöxtur afpreyingar og tómstundastarfsemi verið umtalsvert meiri en í öðrum greinum. Fjöldi peirra sem starfaði í afpreyingu rúmlega tvöfaldaðist á árunum 2000 til 2009 og skatttekjur af afpreyingu fimmfölduðust á sama tímabili (Landsbanki Íslands, e.d.).

Í hugum margra er íslenski hesturinn mikilvægur hluti af ímynd Íslands og peirri afpreyingu sem hér er boðið upp á. Hann hefur um árabil verið hluti af markaðssetningu á landinu sem áfangastað fyrir ferðamenn (Schmudde, 2015; Helgadóttir og Dashper, 2016). Samkvæmt upplýsingum frá Ferðamálastofu Íslands, fara 10,5\% erlendra gesta sem koma að hausti, vetri og vori á hestbak og 14,2\% peirra sem koma að sumri (Oddný Póra Óladóttir, 2015). Sé miðað við heildarfjölda erlendra ferðamanna sem komu til landsins á árinu 2015 (Ferðamálastofa, 2016) má áætla að um 150.000 erlendir gestir hafi greitt fyrir að fara á hestbak á Íslandi. Er pá ótalinn sá fjöldi Íslendinga sem ferðast á eigin vegum á hestum og/eða njóta pjónustu hestaferðafyrirtækja. Hér eru einnig undanskildir peir innlendu og erlendu gestir sem nýta sér hestatengda ferðapjónustu sem ekki felst í að fara á hestbak. Sem dæmi um slíka pjónustu má nefna margvíslegar sýningar og hestaleikhús. Upplýsingar um fjölda gesta og umfang slíkrar pjónustu eru pví miður takmarkaðar sem og upplýsingar um fjölda starfa í greininni (Sigurðardóttir, 2015; Sigurðardóttir og Helgadóttir, 2015b).

Sé litið til fyrirtækja í hestamennsku, par með talið í hestaferðapjónustu, hafa rannsóknir bent til pess að algengt sé að pau beri einkenni lífsstílsfyrirtækja (e. lifestyle enterprise) og að pau séu oft á tíðum tilkomin vegna áhuga og/eða ástríðu rekstraraðilanna fyrir hestum og hestamennsku (Helgadóttir, 2006; Helgadóttir og Sigurðardóttir, 2008; Andersson Cederholm og Hultman, 2010; Liljenstolpe, 2009; Sigurðardóttir, 2015). Takmarkaðar rannsóknir hafa verið gerðar hérlendis á pví hvernig og hvers vegna áhugamál eða lífsstíll fólks í hestamennsku próast yfir í ferðavöru og fyrirtæki sem tekur á móti fjölda ferðamanna ár hvert. Hugtakið ferðavara hefur víða verið skilgreint í tengslum við umfjöllun um ferðamennsku og áfangastaði. Smith (1994) taldi hugtakið samsett úr fimm páttum p.e. ápreifanlegu umhverfi (e. physical plant), pjónustu (e. service), gestrisni (e. hospitality), frelsi til að velja (e. freedom of choice ) og pátttöku (e. involvement). Ferðavara er pannig margbrotin samsetning ólíkra pátta sem stuðla að upplifun ferðamannsins (Edward Hákon Huibens og Gunnar Pór Jóhannesson, 2013).

Upplýsingar um snertifleti hestamennsku og ferðapjónustu hérlendis eru einnig takmarkaðar pó að bent hafi verið á tengsl pessara greina (Ingibjörg Sigurðardóttir og Runólfur Smári Steinpórsson, 2015). Meginmarkmið peirrar rannsóknar sem hér er kynnt var að rýna í próun fyrirtækja í hestamennsku og skoða pátt ferðapjónustu í peirri próun.

Í pessari rannsókn er rýnt í ofangreinda pætti með pví að leita svara við eftirfarandi spurningum:

1. Hvað einkennir próun fyrirtækja í hestamennsku (e. horse industry) á Íslandi?

2. Hverjar eru helstu ástæður pess að hestamennska sem áhugamál eða lífsstíll er próuð yfir í fyrirtæki?

3. Hver er páttur ferðapjónustu í próun hestamennsku sem atvinnugreinar á Íslandi?

Mikilvægt er að auka pekkingu á próun og eðli fyrirtækja í hestamennsku og ferðapjónustu til að skapa grunn að frekari uppbyggingu og vörupróun í pessum greinum. Rannsóknin var eigindleg og byggði á ítarlegum hálfopnum viðtölum sem tekin voru á Norður- og Suðurlandi við 16 rekstraraðila í fyrirtækjum sem stunda hestatengda starfsemi allt frá frumframleiðslu (hrossarækt) til margvíslegrar hestatengdrar pjónustu svo sem pjónustu við ferðamenn. 


\section{Smáfyrirtæki í landbúnaði og ferðapjónustu}

Fyrirtæki eru gjarnan flokkuð eftir stærðarmælikvörðum, svo sem veltu og starfsmannafjölda. Skilgreiningar á pví hvað eru örfyrirtæki, smáfyrirtæki og stórfyrirtæki eru nokkuð misjafnar eftir pví hver skilgreinir. Sem dæmi má nefna að samkvæmt skilgreiningum Hagstofu Ástralíu eru fyrirtæki með allt að 100 starfsmenn talin vera smáfyrirtæki (Hing, 2001). Evrópusambandið skilgreinir smáfyrirtæki sem fyrirtæki með færri en 50 starfsmenn en fyrirtæki með færri en 10 starfsmenn sem örfyrirtæki. Fleiri pættir hafa pó áhrif á pessar skilgreiningar svo sem velta og efnahagur (Davíð S. Davíðsson, Finnur Oddsson, Frosti Ólafsson og Haraldur I. Birgisson, 2009). Í almennu tali er algengt að litið sé á fyrirtæki með allt að 20 starfsmenn sem smáfyrirtæki (Getz, Carlsen og Morrison, 2005).

Á Íslandi eru örfyrirtæki og smáfyrirtæki mikilvægur hluti atvinnulífsins, ekki síst í pjónustugreinum eins og ferðapjónustu. Rúmlega 90\% allra fyrirtækja á landinu flokkast sem örfyrirtæki samkvæmt skilgreiningum Evrópusambandins en um 7\% flokkast sem lítil fyrirtæki. Alls eru pví um 97\% allra fyrirtækja á landinu með 1-50 starfsmenn og falla undir pá skilgreiningu að vera ör- eða smáfyrirtæki (Davíð S. Davíðsson ofl., 2009). Líkt og erlendis virðist sérhæfing starfa í litlum og meðalstórum fyrirtækjum hérlendis aukast eftir pví sem fyrirtækin eru stærri. Líkur pess að fyrirtæki hafi starfsmannastefnu og starfslýsingar fyrir stjórnendur og starfsmenn eru einnig meiri í stórum fyrirtækjum en smáum. Í rannsókn meðal stjórnenda í litlum og meðalstórum fyrirtækjum hér á landi kom fram að aðeins um helmingur fyrirtækjanna var með starfsmannastefnu og um 45\% höfðu starfslýsingu fyrir stjórnendur og enn lægra hlutfall fyrirtækjanna hafði starfslýsingar fyrir aðra starfsmenn (Ingi Rúnar Eðvaldsson, 2009).

Umtalsverðar rannsóknir hafa verið gerðar á undanförnum árum á fyrirtækjum í ferðapjónustu og landbúnaði (Løseth, 2014). Mikill fjöldi smárra fyrirtækja er einkennandi fyrir pessar greinar (Thomas, Shaw og Page, 2011) en meðal pess sem talið er til sameiginlegra einkenna smárra fyrirtækja í ferðapjónustu og landbúnaði er að pau eru að jafnaði í eigu og stjórnað af einstaklingi/einstaklingum sem aflað hafa eigin fjármagns til að koma fyrirtækjunum á fót og sem sjá sjálfir um ákvarðanatöku í rekstrinum. Slík fyrirtæki hafa oft litla markaðshlutdeild og er algengt að stór hluti af vörum peirra og pjónustu sé seldur kaupendum í nágrenni peirra (Hing, 2001).

Sé litið til íslenskra afpreyingarfyrirtækja, telja stjórnendur peirra að pættir eins og smæð fyrirtækjanna, skortur á fjármagni, dýr og ómarkviss markaðssetning, erfiðleikar við stjórnun, lélegt skipulag og lítil stöðlun og fagmennska hamli aukinni framleiðni í afpreyingargreinum (Ingibjörg Sigurðardóttir, 2011). Rannsóknir meðal rekstraraðila í hestamennsku hafa jafnframt bent til að vinnuálag sé mikið, vinnudagar langir og störfin fjölpætt og að slíkt komi á endanum niður á heilsu og almennri velferð rekstraraðilanna. Prátt fyrir pað er meirihluti svarenda ánægður með lífsgæði sín (Tuneberg og Mustonen, 2015). Íslenskar rannsóknir meðal rekstraraðila í hestamennsku, par með talið í hestaferðapjónstu, benda til að hérlendis sé staðan ekki ósvipuð hvað varðar mikið vinnuálag og margbreytileg störf sem rekstraraðilar purfa að sinna (Helgadóttir og Sigurðardóttir, 2008; Sigurðardóttir, 2015; Sigurðardóttir og Helgadóttir, 2015b).

Hin fjölpættu og krefjandi hlutverk rekstraraðilanna koma víða fram, pví auk pess að annast hesta, heyskap og önnur störf tengd búrekstri, parf að sinna bókhaldi, rekstri og markaðsmálum (Helgadóttir og Sigurðardóttir, 2008; Tuneberg og Mustonen, 2015). Hluti af pví að eiga eða halda skepnur er að tryggja velferð peirra samkvæmt reglum par að lútandi (Lög um velferð dýra nr. 55/2013) en einnig er umræða um siðferðisleg álitamál varðandi pað 
að nota dýr í ferðapjónustu sífellt að aukast (Fennell, 2012). Rekstraraðilar í hestaferðapjónustu purfa auk pessa að huga að væntingum, pörfum og upplifun gesta sinna en liður í pví er m.a. að velja saman knapa og hest í peim tilfellum sem gestir fara á hestbak (Ingibjörg Sigurðardóttir og Guðrún Helgadóttir, 2006; Sigurðardóttir og Helgadóttir, 2015a).

\section{Mikilvægi lífsstíls, fjölskyldu og ferðapjónustu í dreifbýli}

Ferðapjónusta á bújörðum hefur umtalsverð áhrif á samfélög í dreifðum byggðum. Prátt fyrir próun í átt að stórum búum par sem stærðarhagkvæmni er höfð að leiðarljósi er raunin sú að langflest bú í hefðbundnum landbúnaði eru rekin sem fjölskyldufyrirtæki. Eru fyrirtækin nátengd lífstíl og áhuga rekstraraðilanna (Ollenburg og Buckley, 2007). Fyrirtæki sem stofnuð eru út frá áhugamáli eða lífsstíl stofnanda eða fjölskyldu hans eru að nokkru leyti frábrugðin öðrum fyrirtækjum. Ástæður og markmið stofnenda bera pess merki að fleiri pættir en peningalegir liggi að baki pví að fyrirtækin eru stofnuð. Ekki er í slíkum fyrirtækjum litið á fjárhagslega mælikvarða sem einu eða ákjósanlegustu leiðina til að meta hvernig til hefur tekist í rekstrinum (Ateljevic og Doorne 2000; Walker og Brown 2004). Í lífsstílsfyrirtækjum eru atriði sem lúta að lífsgæðum og lífsstíl fyrirferðarmeiri en arðsemiskrafa og vöxtur. Рað hefur til dæmis sýnt sig að meðal ástæðna fyrir pví að slík fyrirtæki séu stofnuð eru pættir á borð við að geta búið á ákveðnum stað, að geta eytt meiri tíma með fjölskyldunni og að geta stundað áhugamál sín (Ateljevic og Doorne, 2000; Andersson Cederholm og Hultman, 2010; Sigurðardóttir, 2015). Rannsókn Walkers og Brown (2004) benti til að algengt sé að árangur sé metinn út frá atriðum eins og eigin ánægju og framgangi, að geta verið stoltur af sínu starfi og að geta búið við pann sveigjanleika sem starf innan lífsstílsfyrirtækja býður upp á. Pessir pættir vegi pví pyngra en рað að skapa fjárhagslegan auð.

Frá sjónarhóli stjórnvalda er litið á landbúnaðarferðapjónustu (e. agritourism) sem fjárhagslega líflínu fyrir samfélög í dreifbýli, en ferðapjónustan sér hana sem aðdráttarafl sem stuðlar að aukinni dreifingu ferðamanna út frá péttbýlinu (Ollenburg og Buckley, 2007). Landbúnaðarferðapjónusta er undirgrein ferðapjónustu í dreifbýli (e. rural tourism). Slík ferðapjónusta fer fram á bændabýlum par sem gestir fá með einum eða öðrum hætti að taka pátt í athöfnum á bæjunum s.s. að sjá um búfé. Algengt er að landbúnaðarferðapjónusta sé sett á fót til að auka nýtingu vannýttra auðlinda s.s. húsa, mannafla eða bústofns (Sznajder, Prezezbórska og Scrimgeour, 2009). Sum form hestaferðapjónustu svo sem hestaleiga og hestaferðir hafa verið skilgreind sem landbúnaðarferðapjónusta (Helgadóttir og Sigurðardóttir, 2008). Ollenburg og Buckley (2007) benda á að hvatning bænda til að hefja ferðapjónustu sé mismunandi eftir aðstæðum fjölskyldu, bús og rekstrar. Par hafi bæði félagslegir og efnahagslegir pættir áhrif. Aukinn kostnaður við aðföng til hefðbundins landbúnaðar, samhliða lágu verði á afurðum og auknum sköttum, hefur m.a. orðið til pess að bændur í Ástralíu og Bandaríkjunum hafa leitað leiða til að efla landbúnaðartengda ferðapjónustu (Ollenburg og Buckley, 2007; Pegas, Ollenburg og Tynon, 2013).

Meðal ástæðna fyrir aukinni ferðapjónustu á bújörðum eru kynslóðaskipti (Evans og Ilbery, 1989; Ollenburg og Buckley, 2007). Leitað er leiða til að auka tekjumöguleika og fjölga störfum á býlunum á meðan ný kynslóð er að koma sér fyrir og sú eldri er að undirbúa starfslok. Pá er litið á ferðapjónustu sem leið til að auka líkur pess að jarðir haldist í ábúð. Sumir rekstraraðilar leggja auk pess áherslu á mikilvægi pess að fræða ferðamenn um landbúnað (Ollenburg og Buckley, 2007). Vísbendingar hafa komið fram um að afkomendur peirra sem stofna lífsstílsfyrirtæki, t.d. í ferðapjónustu, taki sjaldan við rekstrinum vegna hugmyndar peirra um að reksturinn sé enginn dans á rósum en að í peim tilfellum sem 
lífsstílsfyrirtæki í ferðapjónustu ganga milli kynslóða, hafi pau reynst vera efnahagslega sjálfbær (Getz, Carlsen og Morrison, 2005).

\section{4 Árstíðabundin starfsemi}

Árstíðasveifla er oft mikil í ferðapjónustu og á pað ekki síst við í litlum og meðalstórum fjölskyldufyrirtækum í dreifbýli. Sum fyrirtæki í pessari stöðu bjóða pjónustu sína aðeins hlusta úr árinu (Helgadóttir og Sigurðardóttir, 2008; Løseth 2014). Árstíðasveifla hefur víðtæk áhrif á rekstur og próun fyrirtækjanna, ekki hvað síst pegar kemur að pjálfun og fræðslu starfsfólks (Dhar, 2015) en algengt er að sjálfboðaliðar, fjölskylda, vinir og vandamenn hlaupi undir bagga á álagstímum í litlum fjölskyldufyrirtækjum í ferðapjónustu (Løseth, 2014; Thuneberg og Mustoenen, 2015). Á mörgum áfangastöðum ferðamanna er lögð áhersla á að draga úr árstíðasveiflu í ferðapjónustu og auka pannig nýtingu húsnæðis, mannafla og annarra framleiðslupátta. Bent hefur verið á ýmsa galla mikillar árstíðasveiflu svo sem mikið vinnuálag í stuttan tíma, mikla starfsmannaveltu, takmarkaða pjálfun starfsmanna og neikvæð áhrif pessara pátta á gæði pjónustu (Kyriakidou og Maroudas, 2010; Faldetta, Fasone og Provenzano, 2013).

Margir rekstraraðilar vilja halda starfsemi sinni gangandi allt árið. Vísbendingar eru pó um að í sumum tilfellum sé pað ósk rekstraraðila í landbúnaðartengdri ferðapjónustu að halda í árstíðasveifluna til að geta sinnt öðrum verkefnum á peim tíma sem eftirspurn eftir ferðapjónustu er í lágmarki. Рað að geta aðlagað ferðapjónustuna að annarri starfsemi búsins og pörfum fjölskyldunnar virðist pví vera mörgum rekstraraðilum mikilvægara en vöxtur ferðapjónustuhlutans (Getz og Nilsson, 2004). Rannsóknir á hestaferðapjónustu á Íslandi hafa sýnt að algengt er að peir sem bjóða hestaferðapjónustu stundi samhliða annan landbúnað eða hestamennsku eða starfi utan heimilis á lágönn ferðapjónustunnar (Helgadóttir og Sigurðardóttir, 2008). Prátt fyrir að vísbendingar séu um að landbúnaðartengd ferðapjónusta skapi minni tekjur en væntingar stóðu til í upphafi (Hjalager, 1996) hefur hún víða reynst gagnleg að pví marki að hún fjölgar tekustofnum lítilla fjölskyldufyrirtækja og styrkir tekjugrundvöll peirra (Pegas, Ollenburg og Tynon, 2013).

\section{Rannsóknaraðferð}

Í rannsókninni er leitast við að svara pví hvað einkenni próun fyrirtækja í hestamennsku á Íslandi, hverjar séu helstu ástæður pess að hestamennska sem áhugamál eða lífsstíll er próuð yfir í fyrirtæki og hver sé páttur ferðapjónustu í pessari próun hérlendis. Rannsóknin var eigindleg og framkvæmd í gegnum hálfopin viðtöl við rekstraraðila í hestamennsku. Eigindlegar rannsóknir henta vel pegar ætlunin er að fá upplýsingar um og öðlast skilning á skoðunum, reynslu og gjörðum ákveðinna einstaklinga. Pær eru gagnlegar til að skilgreina óápreifanlega pætti og geta hjálpað til við að ná yfirgripsmiklum skilningi á viðfangsefninu (Creswell 2007; Blumberg, Cooper og Schindler, 2005). Creswell (2007) bendir á að petta sé aðeins mögulegt að gera með pví að tala við fólk, heimsækja pað á heimili pess eða starfstöðvar og leyfa pví að tjá sig óháð pví hvaða hugmyndir rannsakandi hefur sjálfur um viðfangsefnið.

Í rannsókninni er lögð áhersla á pessa hugmyndafræði og voru viðtölin ýmist tekin á heimilum viðmælenda eða á kaffistofum hesthúsa peirra. Lögð var áhersla á að viðmælandinn segði sögu sína og útskýrði hvata pess að hann stofnaði fyrirtækið. Í eigindlegum rannsóknum er lögð áhersla á að pátttakandi rannsóknarinnar sé virkur túlkandi raunveruleikans pegar 
hann segir frá eigin reynslu (Blumberg, Cooper og Schindler, 2005). Í viðtölunum voru viðmælendur m.a. beðnir að lýsa upphafi og próun fyrirtækjanna og hvers vegna pau hefðu próast á pann veg sem raun bar vitni. Spurt var út í eðli starfseminnar og leitað eftir tengslum hestamennsku og ferðapjónustu í viðkomandi rekstri og hvernig pau tengsl væru til komin. Viðtölin voru tekin á tímabilinu frá apríl 2013 til maí 2014. Pau voru hljóðrituð með stafrænu upptökutæki og síðan afrituð. Greining fór fram með kóðun, fyrst opinni kóðun par sem gögnin voru flokkuð, pá með markvissri kóðun og loks með öxulkóðun par sem meginniðurstöður voru dregnar fram (Creswell, 2007).

Í pessum hluta rannsóknarinnar, sem er hluti af stærra rannsóknarverkefni, byggir greiningin á 16 viðtölum við rekstraraðila í hestamennsku. Alls voru 25 viðtöl í gagnasafninu en aðeins 16 hentuðu til pessarar greiningar. Nánara yfirlit yfir viðmælendur og fyrirtækin sem tóku pátt í pessari rannsókn er að finna í töflu 1. Par eru viðmælendum gefin dulnefni sem pó gefa til kynna rétt kyn. Aldur viðmælenda pegar viðtölin voru tekin er aðeins gefinn upp í aldursbili sem spannar áratug til að draga úr hættu á rekjanleika einskakra beinna tilvísana. Í viðtölunum sjálfum var fólk beðið um að lýsa upphafi og tilurð fyrirtækis síns. Í svörum viðmælenda kom iðulega fram að reksturinn byggði á starfi fyrri kynslóða og að kynslóðaskipti hefðu orðið í rekstrinum, án pess að á peim tímapunkti væri sérstaklega verið að horfa á hversu margar kynslóðir hefðu komið að eða átt fyrirtækið. Hér er pví eingöngu gerður greinarmunur á pví hvort viðmælandi (og/eða maki hans) stofnuðu fyrirtækið (auðkennt í töflu eitt sem „1“) eða tóku við rekstri pess af næstu kynslóð á undan (auðkennt í töflu eitt sem „2“). Gögnin veita pví ekki upplýsingar til að segja nákvæmlega til um fjölda kynslóða sem stýrt hafa rekstrinum. Pessu til viðbótar má nefna að í mörgum tilfellum er ljóst að börn viðmælenda (bæði fullorðin og yngri) koma að rekstrinum pótt með mismunandi hætti sé en slíkt er ekki talið með í töflu 1.

Tafla 1. Viðmælendur rannsóknar

\begin{tabular}{|c|c|c|c|}
\hline Nr. & Dulnefni & Aldur í árum & Kynslóð \\
\hline 1 & Margrét & $50-59$ & 2 \\
\hline 2 & Erla & $60-69$ & 2 \\
\hline 3 & Óttar & $40-49$ & 2 \\
\hline 4 & Steinpór & $50-59$ & 2 \\
\hline 5 & Emma & $40-49$ & 1 \\
\hline 7 & Jón & $50-59$ & 2 \\
\hline 8 & Viktoría & $30-39$ & 1 \\
\hline 10 & Helga & $50-59$ & 1 \\
\hline 12 & Eydís & $40-49$ & 1 \\
\hline 16 & Arnar & $40-49$ & 2 \\
\hline 18 & Haraldur & $30-39$ & 2 \\
\hline 20 & Eva & $40-49$ & 1 \\
\hline 21 & Svavar & $50-59$ & 1 \\
\hline 22 & Kjartan & $40-49$ & 1 \\
\hline 23 & Hólmar & $50-59$ & $40-49$ \\
\hline 24 & Sigrún & . & 2 \\
\hline
\end{tabular}

Pátttakendur í rannsókninni voru valdir með tilgangsúrtaki en par er markmiðið að velja viðmælendur sem henta best markmiði rannsóknarinnar (Katrín Blöndal og Sigríður Halldórsdóttir, 2013). Viðmælendur í rannsókninni höfðu hrossarækt, tamningar og pjálfun og/eða hestaferðapjónustu sem meginpætti atvinnustarfsemi sinnar. Viðmælendur voru allir 
búsettir á Norður- eða Suðurlandi. Á peim svæðum er fjöldi hrossa á íbúa meiri en í öðrum landshlutum (Sigurðardóttir og Helgadóttir, 2015b). Leitast var við að viðmælendur kæmu frá fyrirtækjum sem hefðu mislanga rekstrarsögu pannig að fyrirtækin sem viðmælendur störfuðu hjá endurspegluðu sem best pá fjölbreytni sem einkennir hestamennsku sem atvinnugrein (Evans, 2015; Sigurðardóttir og Helgadóttir, 2015b). Leitast var við að hafa kynjahlutföll viðmælenda nokkuð jöfn.

\section{Niðurstöður}

Helstu niðurstöðum rannsóknarinnar eru hér gerð skil í tveimur köflum. Í fyrri kaflanum er fjallað um próun, uppbyggingu og einkenni fyrirtækja í hestamennsku. Par er leitast við að draga fram svör við pví hvað einkenni próun fyrirtækja í hestamennsku hérlendis og hverjar séu helstu ástæður pess að fyrirtæki í greininni próuðust frá lífsstíl eða áhugamáli yfir í fyrirtæki. Í seinni kaflanum er rýnt í vísbendingar um mikilvægi ferðapjónustu í próun hestamennsku sem atvinnugreinar á Íslandi.

\subsection{Upphaf, próun og einkenni fyrirtækja í hestamennsku}

Niðurstöður pessarar rannsóknar benda til að fyrirtæki í hestamennsku á Íslandi séu í flestum tilfellum fremur smá fjölskyldufyrirtæki pó að ekki sé hægt að alhæfa um pað út frá pessari rannsókn. Fyrirtækin eru gjarnan rekin af a.m.k. annarri kynslóð rekstraraðila auk pess sem að algengt er að börn, tengdabörn og aðrir ættingjar og vinir komi að rekstrinum með einum eða öðrum hætti. Í sumum tilfellum byggja fyrirtækin á öðrum rekstri svo sem í landbúnaði eða ferðapjónustu. Athygli vekur að prátt fyrir að viðmælendur séu flestir á aldrinum 40-60 ára hefur um helmingur peirra tekið við rekstrinum og/eða próað hann út frá atvinnustarfsemi næstu kynslóðar á undan, innan sömu fjölskyldu. Margrét segir t.d: Tengdafađir minn var búinn að vera lengi i hrossarækt og eiga góð hross. Við svo komum með ferðapjónustuna inn í petta. Erla hefur hins vegar ásamt eiginmanni sínum tekið við rekstri foreldra sinna. Hún segir: ...náttúrulega pabbi byrjaði í pessu [hrossaræktinni]'66, pað er eiginlega grunnurinn. Fjölskyldan virðist pví vera mikilvæg í rekstrinum eða eins og Haraldur segir: ...svona í raun og veru algjörlega fjölskyldan sem stendur í pessu, krakkarnir mínir hjálpa mér og allir, pað taka allir pátt í pessu.

Í viðtölunum kemur skýrt fram að áhugamál eða lífsstíll í hestamennsku var forsenda pess að menn stofnuðu hestatengd fyrirtæki. Allir viðmælendur taka pað skýrt fram að peir hafi verið búnir að vera í hestamennsku um árabil, jafnvel alla ævi áður en peir hófu rekstur fyrirtækja sinna. Enginn viðmælendanna nefndi að fyrirtækin hefðu verið stofnuð með peningalegan ábata sem meginmarkmið. Viðtölin gefa tilefni til að ætla að menn stofni fyrirtæki til að geta átt hross og land fremur en að menn kaupi hross og tilheyrandi búnað til að geta hafið rekstur. Auk pessa meginhvata að stofnun fyrirtækjanna er algengt að menn séu að styrkja búsetugrundvöll á ákveðnum stöðum, skapa fjölskyldunni atvinnu, bæta nýtingu pess sem til staðar er, s.s. hesta, bygginga, lands, búnaðar og mannafla, sem og að mæta eftirspurn í nánasta umhverfi. Hvatinn er pví að nokkru leyti efnahagslegur.

Fyrirtækin hafa að jafnaði verið byggð upp smátt og smátt án pess að tekin hafi verið veruleg fjárhagsleg áhætta. Steinpór segir: ...en ég held nú að sé nú bara með petta eins og aðrar atvinnugreinar að sígandi lukka sé best og menn fari bara rólega í petta og menn byggi petta upp varlega. Hluti af pví að byggja upp fyrirtæki án pess að fara í miklar fjárfestingar eða taka umtalsverða fjárhagslega áhættu virðist vera fjölhæfni stofnenda og áhersla peirra á að bjarga sér sjálfir með раð sem gera parf í stað pess að kaupa pjónustu frá öðrum í miklum mæli. Haraldur segir: ...gerum mjög mikið sjálf og höldum pannig kostnađi sko í lágmarki. Sigrún segir jafnframt: Pú ert að 
laga girðingar, pú ert að heyja, pú ert að gera allt. Pessi páttur virðist vera mikilvægur til að skapa forsendur pess að fyrirtækin geti komist af fjárhagslega en er ef til vill líka ákveðinn hluti af lífsstíl rekstraraðilanna. Prátt fyrir petta leggja viðmælendur ríka áherslu á samfélagið og pað að fyrirtækin skili ábata til annarra í umhverfinu t.d. með peim hætti að keypt sé hagaganga eða önnur pjónusta af bændum í löngum hestaferðum.

Annar páttur sem virðist vera mikilvægur til að byggja fyrirtæki upp án utanað komandi fjármagns og að reka pað með efnahagslega sjálfbærum hætti er að nýta fjölbreyttar leiðir til að afla tekna. Starfsemin í heild byggir gjarnan á pví að tekjur komi frá mörgum páttum, svo sem frá hrossarækt, tamningum, járningum, reiðkennslu og hestaferðapjónustu. Einnig er algengt að rekstraraðilar vinni hluta úr ári utan heimilis eða stundi aðra starfsemi svo sem sauðfjárrækt. Prátt fyrir að vera með á annað hundrað hrossa virðist Erla t.d. fremur treysta á stöðugar tekjur af sauðfé en hrossum: Já, við erum með pessi hross og náttúrulega sauðféð með, eða hrossin eru uppbót á sauðféð [hlær], við skulum hafa pað pannig poí að maður veit aldrei hvenær maður selur hross. Rekstraraðilar virðast láta hverjum degi nægja sína pjáningu ef svo má að orði komast og bregðast t.d. við samdrætti með pví að sækja sér vinnu utan heimilis pegar pörf krefur.

\subsection{Ferðapjónusta sem hluti af próun hestamennsku sem atvinnugreinar}

Í hestasýningum, hestaleigum, lengri hestaferðum og annarri hestatengdri ferðapjónustu birtast hvað skýrast tengsl ferðapjónustu og hestamennsku. Niðurstöður pessarar rannsóknar benda til að fólk í hestatengdum rekstri líti á ferðapjónustu sem tækifæri til að styrkja hestamennsku sem atvinnugrein. Allmargir viðmælenda tala um að erfitt hafi verið á undanförnum árum að halda gangandi fyrirtækjum sem byggja fyrst og fremst á hrossarækt, enda hafi sala hrossa verið dræm um nokkurt skeið. Í kjölfarið virðast rekstraraðilar huga að nýjum leiðum til tekjuöflunar, ekki hvað síst á sviði ferðapjónustu. Rekstraraðilar telja vera eftirspurn eftir hestaferðapjónustu í háum gæðaflokki, t.d. hvað varðar hestakost. Hólmar segir til dæmis: ...vantar hestaferðir sem að eru lúxusferðir fyrir vana hestamenn erlendis frá sem eru tilbúnir að borga. Að vera á góðum hestum, hestum eins og við viljum sjálfir, peir sem eru vanir hestum hérna heima. Rekstraraðilar nefna einnig fræðslutengda hestaferðapjónustu t.d. í pví formi að gestir komi til Íslands á reiðnámskeið eða nokkurs konar reiðskóla hjá pekktum knöpum og á góðum hestum allt upp í virka keppnishesta. Einnig var nefndur sá möguleiki að bjóða bóklegan hluta pjónustunnar á netinu. Viktoría útskýrir sínar hugmyndir og uppbyggingu síns fyrirtækis með áherslu á fræðslutengda pjónustu og segir m.a: ...að fá fólk hingað í reiðkennslu og pannig og jafnvel kannski meira í gegnum tölvu.

Eins og áður sagði er samsetning fyrirtækjanna mismunandi og nýta rekstraraðilar ólíkar leiðir til að afla sér tekna. Að sama skapi er efnahagslegt mikilvægi ferðapjónustu í rekstrinum í heild mismunandi innan fyrirtækja. Niðurstöður pessarar rannsóknar benda til að flokka megi mikilvægi hestamennsku og ferðapjónustu innan hestatengdra fyrirtækja hérlendis í prjá flokka: hestamennsku án ferðapjónustu, blandaða starfsemi og hreina hestatengda ferðapjónustu (tafla 2).

Tafla 2. Mismunandi vægi ferðapjónustu innan hestatengdra fyrirtækja 


\begin{tabular}{|l|l|l|l|}
\hline & $\begin{array}{l}\text { Hestamennska án } \\
\text { ferðapjónustu }\end{array}$ & Blönduð starfsemi & $\begin{array}{l}\text { Hrein hestatengd } \\
\text { ferðapjónusta }\end{array}$ \\
\hline $\begin{array}{l}\text { Lítil áhrif ferðapjónustu } \\
\text { innan hestamennsku }\end{array}$ & $\begin{array}{l}\text { Ræktun, tamningar, pjálfun, } \\
\text { sala }\end{array}$ & $\begin{array}{l}\text { Ræktun, tamningar, pjálfun, } \\
\text { sala, hestaferðir, } \\
\text { hestasýningar, önnur } \\
\text { starfsemi/atvinna }\end{array}$ & \\
\hline $\begin{array}{l}\text { Miðlungs áhrif } \\
\text { ferðapjónustu innan } \\
\text { hestamennsku }\end{array}$ & $\begin{array}{l}\text { Mikil áhrif } \\
\text { ferðapjónustu innan } \\
\text { hestamennsku }\end{array}$ & $\begin{array}{l}\text { Hestaleiga, hestaferðir, } \\
\text { hestasýningar, hestaleikhús, } \\
\text { minjagripir }\end{array}$ \\
\hline
\end{tabular}

Vægi ferðapjónustu innan fyrirtækjanna eykst eftir pví sem stærri hluti af tekjum peirra kemur frá pjónustu við ferðamenn. Pví má segja að ferðapjónusta hafi lítil áhrif innan hestamennskunnar í peim tilfellum par sem eingöngu er um að ræða starfsemi sem byggir á frumframleiðslu og úrvinnslu, pað er ræktun, tamningum, pjálfun og sölu hrossa. Áhrif ferðapjónustu innan hestamennsku aukast svo eftir pví sem páttur beinnar ferðapjónustu verður fyrirferðarmeiri í rekstrinum. Pannig er vægi ferðapjónustu innan fyrirtækja sem bjóða eingöngu upp á hestaferðapjónustu, eðli málsins samkvæmt mikið (tafla 2) en pessum flokkum verða gerð nánari skil hér á eftir.

Pau fyrirtæki sem ekki hafa beinar tekjur af ferðapjónustu má flokka sem hestamennsku án ferðapjónustu (tafla 2). Pau fyrirtæki virðast pó hafa óbein tengsl við ferðapjónustu. Hrossarækt, tamningar og sala hrossa eru pess eðlis að menn ferðast töluvert í sínu starfi. Sem dæmi má nefna að menn fara oft um langan veg með hryssur undir stóðhesta auk pess að fara á keppnir og sýningar ýmist til að taka pátt eða sem áhorfendur. Viðskiptavinir pessara fyrirtækja ferðast einnig nokkuð í tengslum við viðskiptin. Sem dæmi um pað má nefna að peir koma langt að með hross í tamningu og pjálfun og ferðast til að skoða hross sem ef til vill er ætlunin að kaupa.

Ferðapjónusta er oft á tíðum töluverður hluti af heildarstarfsemi hestatengdra fyrirtækja. Má flokka slíkt sem blandaða starfsemi (tafla 2). Starfsemi slíkra fyrirtækja getur verið með ýmsu móti. Algengt er að stunduð sé hrossarækt, tamningar og pjálfun auk pess sem boðið er uppá stuttar og/eða eða langar hestaferðir yfir sumartímann. Einnig eru allmörg dæmi um að boðið sé upp á annars konar vöru eða pjónustu svo sem gistingu, veitingar, minjagripi eða leiðsögn. Algengt er að hrossaræktendur bjóði upp á margpætta pjónustu við pá sem koma til peirra til að kaupa hross eða selji hross í kjölfar hestaferða. Pó að hér séu í raun aðeins talin nokkur dæmi um tengsl hestamennsku og ferðapjónustu pá sést af pessari upptalningu hversu fjölbreytilegu hlutverki ferðapjónustan gegnir í peim fyrirtækjum sem hafa tekjur bæði af ferðapjónustu og margvíslegri hestatengdri starfsemi. Virðist pessi fjölbreytileiki og pað að nýta fjölpættar leiðir til að komast af vera einkennandi og pví má ætla að nokkuð stór hluti fyrirtækjanna 16 falli í pennan flokk.

Í priðja flokknum eru fyrirtæki sem hafa allar sínar tekjur eða meginhluta peirra af ferðapjónustu (tafla 2). Par er um að ræða hestaferðapjónustu sem rekin er allt árið. Gjarnan er pá verið með hestaleigu að vetri en bæði hestaleigu og langar hestaferðir yfir sumartímann. Hestasýningar sem settar eru upp sérstaklega fyrir ferðamenn virðast einnig vera í vexti. Hólmar nefnir auk pess sóknarfæri í nágrenni Reykjavíkur í pví að bjóða upp á afpreyingu sem felur í sér stutta viðdvöl gesta, pað að fá að sjá hestinn og komast í návígi við hann. Peir aðilar sem hafa tekjur sínar fyrst og fremst af ferðapjónustu eru gjarnan með fjölpættari 
ferðapjónustu en sem lýtur að hestunum. Má par nefna gistingu, veitingasölu, minjagripasölu og afpreyingu sem ekki tengist hestum beint.

\section{Umræða}

Eins og fram hefur komið hafa fyrirtæki í hestamennsku hérlendis mörg einkenni lífsstílsfyrirtækja (Sigurðardóttir, 2015). Svo virðist sem pað að geta viðhaldið sínum lífsstíl, styrkt búsetu á ákveðnum stað eða svæði og aukið samveru og/eða samvinnu við fjölskylduna sé stofnendum mikilvægara en pað að sjá fyrirtækin vaxa hratt eða skila peningalegum ábata pó að almennt sé lögð áhersla á að fyrirtækin komist af fjárhagslega (Helgadóttir og Sigurðardóttir, 2008; Sigurðardóttir, 2015). Áhersla á fjölskylduna er áberandi og ljóst að stór hluti fyrirtækjanna getur flokkast sem fjölskyldufyrirtæki (Sigurðardóttir, 2015).

\subsection{Frá lífsstíl til ferðavöru}

Ummæli viðmælenda í pessari rannsókn benda til pess að fjárhagslega sé reksturinn ekki auðveldur og hafi ekki verið en einhvern veginn tekst mönnum pó að halda fyrirtækjunum gangandi. Steinpór hefur verið lengi í hestatengdum rekstri. Hann segir t.d. við lifum á pessu í dag og erum búin að gera pað nú í nokkur ár en petta er langhlaup. Hann segir einnig: ...höfum alltaf farið mjög gætilega i allar fjárfestingar, að eyða nú ekki meira en efni standa til. Svipuð ummæli komu frá fleiri rekstraraðilum. Benda pau til ákveðinnar varfærni í fjárfestingum og framkvæmdum.

Eins og áđur sagði hafa komið fram vísbendingar um að afkomendur rekstraraðila í lífsstílsfyrirtækjum svo sem í landbúnaði og ferðapjónustu taki ógjarnan við rekstrinum vegna peirrar ímyndar að reksturinn sé erfiður (Getz, Carlsen og Morrison, 2005). Niðurstöður peirrar rannsóknar sem hér er kynnt benda hins vegar til pess að algengt sé að afkomendur peirra sem stofna hestatengd fyrirtæki taki við peim og haldi rekstrinum áfram ýmist í sama formi eða með breyttu sniði. Í um helmingi tilfella í pessari rannsókn er a.m.k. önnur kynslóð rekstraraðila að reka fyrirtækið. Pessi niðurstaða vekur spurningar um pað hvort fyrirtæki í hestamennsku, par á meðal í hestaferðapjónustu, séu að einhverju leyti farsælli eða fýsilegri til að taka við en almennt gerist með lífsstílsfyrirtæki í ferðapjónustu. Vekur pessi niðurstaða upp spurningar í pá veru hvort fyrirtæki í hestamennsku hérlendis hafi að mati stofnenda og afkomenda peirra reynst árangursrík á sviðum sem skipta menn meira máli en hin peningalega hlið rekstrarins. Velta má fyrir sér hvað pað sé sem geri pað að verkum að fyrirtæki í hestamennsku virðist ganga frekar milli kynslóða en fyrirtæki sem bjóða t.d. fyrst og fremst gistingu og veitingar. Óvíst er hvort pað er áhugi fólks á hestinum eða hrossarækt og hestamennsku almennt sem gengur mann fram af manni og/eða hvort aðrir pættir koma par við sögu svo sem nýting eigna sem menn vilja ekki eða geta ekki selt.

Út frá pessari rannsókn er ekki mögulegt að fullyrða hvort samsetning fyrirtækja í hestamennsku, pað er hvort eða að hversu miklu leyti ferðapjónusta er hluti af rekstrinum, (tafla 2) skipti máli varðandi pað hvort fyrirtæki ganga milli kynslóða eða ekki. Eins og fram hefur komið er uppbygging ferðapjónustu á bújörðum gjarnan liður í kynslóðaskiptum og pá ákveðin leið til að skapa auknar tekjur (Evans og Ilbery, 1989; Ollenburg og Buckley 2007). Petta kemur einnig nokkuð sterkt fram í viðtölum pessarar rannsóknar pegar viðmælendur lýsa fyrirtækinu og uppbyggingu pess. Gott dæmi um pað er lýsing Margrétar á hrossarækt tengdaföður síns sem síðan próast yfir í að sonur hans, maður Margrétar, fer að bjóða ferðamönnum hestaferðir.

Ætla má að pað að reksturinn byggir á lifandi dýrum, p.e. hestum, geri pað að verkum að mikilvægt reynist fyrir rekstraraðila að hafa sterkan bakgrunn í hestamennsku eða öðrum 
landbúnaði og pess vegna kann að vera algengara að peir sem eru uppaldir við hestamennsku taki við rekstrinum. Bent hefur verið á að pað að reka fyrirtæki sem bjóða hestaferðapjónustu útheimti fjölpætta pekkingu og færni par sem unnið er með lifandi dýr og fólk. Má segja að dýrin séu páttur sem kemur til viðbótar við pað sem huga parf að og kunna skil á í ferðapjónustufyrirtækjum eins og t.d. í gisti- eða veitingarekstri. Í hestaleigu og hestaferðum parf t.d. að para saman menn og hesta með peim hætti að hver hestur henti viðkomandi knapa auk pess sem að rekstraraðilar purfa að kunna skil á helstu páttum í rekstri ferðapjónustufyrirtækis (Sigurðardóttir og Helgadóttir, 2015a).

Pví hefur verið haldið fram að lífsstílseinkenni fyrirtækja séu líkleg til að hamla nýsköpun, vexti og próun gæða par sem rekstraraðilar hugsi meira um að viðhalda lífsstíl en að byggja upp fyrirtæki (Getz, Carlsen og Morrison, 2005). Greinilegt er pó að sumir rekstraraðilar í hestamennsku hérlendis hafa byggt upp og próað starfsemi sína a.m.k. að nokkru leyti út frá hugmyndum um markhópa og próun ferðavöru, peir sérhæfa sig á ákveðnum sviðum fremur en að reyna að pjónusta alla hópa viðskiptavina. Á pað ekki hvað síst við í peim tilfellum sem boðið er upp á hestasýningar fyrir ferðamenn. Margrét sem býður m.a. upp á hestasýningar segir t.d. ...gerum pað betur svona, að vera ekki í öllu.

Prátt fyrir pessar vísbendingar má ætla að töluverð tækifæri liggi í aukinni áherslu á vörupróun og greiningu markhópa pegar hugað er að uppbyggingu fyrirtækja í hestamennsku og pá ekki síst í hestaferðapjónustu. Mikilvægt er að hafa í huga að töluverður munur er á væntingum innlendra viðskiptavina og erlendra. Hið sama má segja um pá sem kaupa pjónustu hestaleiga og fara t.d. í klukkutíma reiðtúr og svo hina sem kjósa að fara í langar hestaferðir (Sigurðardóttir og Helgadóttir, 2015a). Ætla má að margir ferðamenn hafi áhuga á að kynnast íslenska hestinum án pess að fara á hestbak. Hefur pjónusta við pá ferðamenn próast hægt og bítandi á undanförnum árum en framboð á hestasýningum fyrir ferðamenn hefur aukist töluvert á undanförnum árum auk pess sem að nýjungar eins og hestaleikhús með tilheyrandi pjónustu, veitingasölu, minjagripasölu o.fl. hafa komið fram (Sigurðardóttir og Helgadóttir, 2015b). Pví má segja að ferðavaran sem slík sé að próast að nokkru marki pó að víða megi vinna meira í peim efnum og huga enn frekar að ólíkum pörfum og væntingum markhópa, sérhæfingu og aðgreiningu ferðavörunnar á markaði.

\subsection{Ferðapjónusta og hestamennska - sóknarfæri}

Rannsóknir benda til mikils fjölbreytileika innan hestatengdra fyrirtækja á heimsvísu (Evans, 2015; The Henley Centre, 2004). Prátt fyrir að stundum sé litið á mikinn fjölbreytileika hestamennsku sem veikleika (Evans, 2015) má ætla að hann geti verið uppspretta tækifæra í vörupróun og nýsköpun. Bent hefur verið á að sú staðreynd að á Íslandi er aðeins eitt hestakyn kunni að valda pví að fjölbreytileiki innan hestamennskunnar sé ekki eins mikill hér á landi og víða annars staðar. Раð kunni hins vegar að auðvelda samvinnu milli ólíkra greina hestamennskunnar hérlendis (Sigurðardóttir og Helgadóttir, 2015b). Fjölbreytileikinn gefur færi á að skapa sérstöðu. Einnig að skilgreina sig og staðsetja á markaði út frá pví sem fyrirtæki hafa upp á að bjóða eða ef pau geta boðið pjónustu betur, hraðar eða með skilvirkari/hagstæðari hætti en aðrir. Fjölbreytileiki greinarinnar og ólík staðsetning fyrirtækja gefa möguleika á að skapa mismunandi upplifun gesta við ólíkar aðstæður ýmist úti í náttúrunni eða innan dyra sem er mikilvægt par sem hestaferðapjónusta snýst um að skapa eftirminnilega upplifun peirra sem pjónustunnar njóta.

Vísbendingar eru um að fjölpætt atvinnustarfsemi jafni tekjuflæði og að öruggara sé að hafa fleiri en einn tekjustofn í hestatengdum fyrirtækjum. Á hinn bóginn má ætla að pað að hafa of fjölpættan rekstur sé krefjandi og geti dregið úr líkum á pví að rekstraraðilar nái að 
sinna hverjum pætti eins vel og æskilegt væri til að hámarka framlegð af rekstrinum. Margrét segist t.d. ekki hafa náð að setja næga orku og tíma í markaðsmálin: ...við höfum ekki róið á miðin...ég viðurkenni pað alveg. Ég hef svolítið svona reynt að halda í horfinu pví sem við höfum. Ekki er mögulegt að gefa skýrar leiðbeiningar um hvað er rétt eða æskilegt í pessu sambandi en hver og einn rekstraraðili verður að finna hvaða samsetning hentar viðkomandi fyrirtæki. Í pví sambandi er mikilvægt að huga að peirri pjónustu sem til staðar er í umhverfi hvers fyrirtækis. Æskilegt er að velta fyrir sér með hvaða hætti hægt er að bæta nýju við pað sem fyrir er á svæðinu og hvernig sú starfsemi sem til staðar er getur stutt við uppbyggingu og próun viðkomandi fyrirtækis. Á svæðum par sem næga gisti- og veitingapjónustu er að finna og straumur ferðamanna er nokkur kunna tækifæri að felast í próun afpreyingar sem hentar peim ferðamönnum sem um svæðið fara, auk pess að vert er að huga að sókn í nýja markhópa sem gera mönnum kleift að breyta áhugamáli eða lífsstíl í atvinnurekstur og/eða efla atvinnustarfsemi sem pegar hefur verið komið á fót. Gagnlegt kann að vera að huga að pví hver er núverandi páttur ferðapjónustu í starfsemi hvers fyrirtækis (tafla 2) og hvort og pá með hvaða hætti er fýsilegt að auka vægi ferðapjónustu í tekjuflæði fyrirtækisins.

\subsection{Aðlokum}

Í rannsókn pessari var leitast við að svara pví hvað einkenni próun fyrirtækja í hestamennsku á Íslandi og hverjar séu helstu ástæður pess að hestamennska sem áhugamál eða lífsstíll próast yfir í fyrirtæki sem og hver sé páttur ferðapjónustu í próun hestamennsku sem atvinnugreinar hérlendis. Rannsóknin leiddi í ljós margpættar vísbendingar um petta viðfangefni en hér er um lítt rannsakað svið að ræða. Próun hestatengdra fyrirtækja hérlendis virðist um margt vera lík pví sem fram hefur komið um próun sambærilegra fyrirtækja erlendis. Sérstaka athygli vekja pó vísbendingar úr pessari rannsókn í pá veru að fyrirtæki í hestamennsku og hestatengdri ferðapjónustu hérlendis kunni að vera líklegri en fyrirtæki í ferðapjónustu almennt til að færast milli kynslóða pannig að nýjar kynslóðir taki við rekstrinum og prói hann áfram. Rannsóknin bendir til að stórfjölskyldan taki gjarnan virkan pátt í starfseminni og má velta fyrir sér hvort pað hafi áhrif í pá veru að afkomendur stofnenda fyrirtækjanna upplifi einhvers konar skuldbindingu eða tengsl við fyrirtækið sem geri pað líklegra en ella að peir taki við rekstrinum.

Ljóst er pó að rannsókn pessi gefur ekki tilefni til að fullyrða eða alhæfa um kynslóðaskipti í hestatengdum fyrirtækjum hérlendis. Hvorki hvað varðar hvetjandi eða letjandi pætti í pví sambandi eða líkur á pví að fyrirtæki í hestamennsku og hestaferðapjónustu hérlendis gangi milli kynslóða en ætla má að pað sé verðugt rannsóknarefni sem áhugavert væri að skoða nánar og pá ef til vill með megindlegum aðferðum og samanburði á próun innlendra og erlendra fyrirtækja í hestamennsku og ferðapjónustu.

\section{Heimildir}

Andersson Cederholm, E. og Hultman, J. (2010). The value of intimacy-negotiating commercial relationships in lifestyle entrepreneurship. Scandinavian Journal of Hospitality and Tourism, 10(1), 16-32. Doi:10.1080/15022250903442096.

Ateljevic, I. og Doorne, S. (2000). "Staying within the fence": Lifestyle entrepreneurship in tourism. Journal of Sustainable Tourism, 8(5), 378-392. Doi:10.1080/09669580008667374. 
Bloomberg, B., Cooper, D.R. og Schindler, P.S. (2005). Business research methods. London: McGraw Hill.

Buchmann, A. (2014). Insights into domestic horse tourism: the case study of Lake Macquarie, NSW, Australia. Current Issues in Tourism. doi:10.1080/13683500.2014.887058.

Creswell, J.W. (2007). Qualitative inquiry and research design: Choosing among five approaches. London: Sage.

Davíð S. Davíðsson, Finnur Oddsson, Frosti Ólafsson og Haraldur I. Birgisson (ritstjórar). (2009). Hugsum hátt - Lítil og meðalstór fyrirtæki. Reykjavík: Viðskiptaráð Íslands.

Dhar, R. L. (2015). Service quality and the training of employees: The mediating role of organizational commitment. Tourism Management, 46, 419-430. Doi.org/10.1016/j.tourman.2014.08.001.

Edward Hákon Huijbens og Gunnar Pór Jóhannesson. (2013). Ferðamál á Íslandi. Reykjavík: Mál og menning.

Evans, N.J. og Ilbery, B.W. (1989). A conceptual framework for investigating farm-based accommodation and tourism in Britain. Journal of Rural Studies, 5(3), 257-266. Doi:10.1016/0743-0167(89)90004-1.

Evans, R. (2015). Introduction to the new equine economy in the $21^{\text {st }}$ century. The development and transformation of the European horse industry. I C. Vial og R. Evans (ritstj.), The new equine economy in the 21 ${ }^{\text {st }}$ century, (bls. 13-17). EAAP publication no. 136. The Netherlands: Wageningen Academic Publishers. http://dx.doi.org/10.3920/978-90-8686-824-7.

Faldetta, G., Fasone, V. og Provenzan, C. (2013). Turnover in the hospitality industry: can reciprocity solve the problem? PASOS. Revista de Turismo y Patrimonio Cultural, 11(4), 583595.

Fennell, D.A. (2012). Tourism and animal ethics. London og New York: Routledge.

Ferðamálastofa. (2016). Heildarfjöldi erlendra ferðamanna 1949-2015. Sótt 28. mars 2016 af http://www.ferdamalastofa.is/is/tolur-og-utgafur/fjoldi-ferdamanna/heildarfjoldierlendra-ferdamanna-1949-2015

Getz, D. og Nilsson P.A. (2004). Responses of family businesses to extreme seasonality in demand: the case of Bornholm, Denmark. Tourism Management, 25(1),17-30. Doi:10.1016/S0261-5177(03)00067-0.

Getz, D., Carlsen J. og Morrison A. (2005). Quality issues for the family business. Í E. Jones og C. Haveng-Tang, (ritstj.), Tourism SMEs, service quality and destination competitiveness, (bls. 73-85). UK:CABI Publishing.

Helgadóttir, G. (2006). The culture of horsemanship and horse-based tourism in Iceland. Current Issues in Tourism, 9(6),535-548. Doi:10/2167/cit297.0.

Helgadóttir, G. og Dashper, K. (2016). „Dear international guests and friends of the Icelandic Horse": Experience, meaninga and belonging at a niche sporting event. Scandinavian Journal of Hospitality and Tourism, 16(4),422-441.

Helgadóttir, G. og Sigurðardóttir, I. (2008). Horse-based tourism: Community, quality and disinterest in economic value. Scandinavian Journal of Hospitality and Tourism, 8(2), 105-121. Doi:10.1080/15022250802088149.

Hing, N. (2001). Entrepreneurship and small business. Í N. Douglas, D., Ngaire og R., Derrett, (ritstj.), Special Interest Tourism, (bls. 56-85). Australia:Wiley.

Hjalager, A.M. (1996). Agricultural diversification into tourism: Evidence of a European Community development programme. Tourism Management 17(2), 103-111. http://dx.doi.org/10.1016/0261-5177(95)00113-1. 
Ingi Rúnar Eðvaldsson. (2009). Mannauðsstjórnun í litlum og meðalstórum fyrirtækjum. Í Auður Hermannsdóttir, Margrét Sigrún Sigurðardóttir og Snjólfur Ólafsson (ritstj.), Vorráðstefna Viðskiptafræðistofnunar Háskóla Íslands, bls. 98-107. Reykjavík: Viðskiptafræðistofnun Háskóla Íslands.

Ingibjörg Sigurðardóttir. (2004). Hestatengd ferðapjónusta á Íslandi. Óbirt lokaritgerð til B.Sc. gráðu í viðskiptafræði við Háskólann á Akureyri. Skoðað 25. apríl 2016 á http://skemman.is/stream/get/1946/1010/1211/1/hestatengd.pdf

Ingibjörg Sigurðardóttir. (2011). Framleiðnihugtakið; pekking og viðhorf stjórnenda í íslenskum afpreyingarfyrirtækjum. Í Auður Hermannsdóttir, Jón Snorri Snorrason og Póra Christiansen (ritstj.), Vorráðstefna Viðskiptafræðistofnunar Háskóla Íslands, bls. 129-139. Reykjavík: Viðskiptafræðistofnun Háskóla Íslands.

Ingibjörg Sigurðardóttir og Guðrún Helgadóttir. (2006). Upplifun og pjónusta: Íslenskir gestir í hestaleigum. Landabréfið, 22(1), 37-47.

Ingibjörg Sigurðardóttir og Runólfur Smári Steinpórsson. (2015). Hestar og próun klasa; hestatengdur klasi á Norðurlandi vestra. Skrína, 2(6), 1-9.

Katrín Blöndal og Sigríður Halldórsdóttir. (2013). Úrtök og úrtaksaðferðir í eigindlegum rannsóknum. Í Sigríður Halldórsdóttir (ritstj), Handbók i aðferðafræði rannsókna, (bls. 129136). Akureyri: Ásprent Stíll ehf.

Kyriakidou, O. og Maroudas, L. (2010). Training and development in British hospitality, tourism and leisure SMEs. Managing Leisure, 15(1/2): 32-47. Doi: 10.1080/13606710903447998

Landsbanki Íslands. (e.d.). Ferðapjónusta á Íslandi. Próun fjárfestingar og reksturs. Sótt 3. maí 2016 af

https://www.landsbankinn.is/library/Documents/Hagfraedideild/Serrit/LB Ferdatjonusta Skyrsla netid.pdf

Liljenstolpe, C. (2009). Horses in Europe. Í C. Lönnell, (ritstj.). Svípjóð: Swedish University of Agricultural Sciences (SLU).

Lög um skiptan ferðamála nr. 73/2005.

Lög um velferð dýra nr. 55/2013.

Løseth, K. (2014). Adventure tourism, exploring relations between knowledge and innovation. Danmark: Aalborg Universitet.

Oddný Póra Óladóttir. (2015). Ferðapjónusta á Íslandi í tölum, apríl 2015. Reykjavík: Ferðamálastofa. Sótt 24. maí 2015 af http://www.ferdamalastofa.is/is/tolur-ogutgafur/ferdtjonusta-i-tolum

Ollenburg, C. og Buckley, R. (2007). Stated economic and social motivations of farm tourism operators. Journal of Travel Research, 45(4), 444-452. Doi: 10:1177/0047287507299574.

Pegas, F.D.V., Ollenburg, C. og Tynon, J.F. (2013). Cattle ranchers and agritourism in Oregon, USA: Motivations, challenges and opportunities from the landowner's perscpective. Tourism Recreation Research, 38(1), 43-54. Doi:10.1080/02508281.2013.11081728.

Pickel-Chevalier, S. og Evans, R. (2015). Equestrian leisure activities, levers for economic development: from adaption to innovation by the professional sector. Cheval, Tourisme $\mathcal{E}$ Sociétés/Horse, Tourism \& Societies, Mondes du Tourisme, special issue - hors série, juin 2015, bls. 125.

Schmudde, R. (2015). Equestrian tourism in national parks and protected areas in Iceland - An analysis of the environmental and social impacts. Scandinavian Journal of Hospitality and Tourism, 15(1-2), 91-104. Doi:10.1080/15022250.2014.1000713. 
Sigurðardóttir, I. (2015). Identifying the success criteria of Icelandic horse-based tourism businesses: interviews with operators. Cheval, Tourisme $\mathcal{E}$ Sociétés/Horse, Tourism $\mathcal{E}$ Societies, Mondes du Tourisme, special issue - hors série, juin 2015, bls. 150-160.

Sigurðardóttir, I. og Helgadóttir, G. (2015a). Riding high: quality and customer satisfaction in equestrian tourism in Iceland. Scandinavian Journal of Hospitality and Tourism, 15(1-2), 105121. Doi: $10.1080 / 15022250.2015 .1015765$.

Sigurðardóttir, I. og Helgadóttir, G. (2015b). The new equine economy in Iceland. Í C. Vial og

R. Evans (ritstj.), The new equine economy in the 21 st century, (bls. 225-236). EAAP publication no. 136. The Netherlands: Wageningen Academic Publishers. Doi:10,3920/978-90-8686-824-7_19.

Smith, S.L.J. (1994). The tourism product. Annals of Tourism Research, 21(3), 582-595.

Sznajder, M., Przezbórska, L. og Scrimgeour, F. (2009). Agritourism. Wallingford, Cambridge, MA: CABI.

The Henley Centre (2004). A report of research on the horse industry in Great Britain. London: Defra Publication.

Thomas, R., Shaw, G. og Page, S.J. (2011). Understanding small firms in tourism: A perspective on research trends and challenges. Tourism Management, 32(5), 963-976, Doi:10.1016/j.tourman.2011.02.003.

Thuneberg, T. og Mustonen, T. (2015). Equine entrepreneur's well-being. Í C. Vial og R. Evans (ritstj.), The new equine economy in the 21st century, (bls. 99-101). EAAP publication no. 136. The Netherlands: Wageningen Academic Publishers. Doi: http://dx.doi.org/10.3920/97890-8686-824-7_8.

Walker, E. og Brown, A. (2004).What success factors are important to small business owners? International Small Business Journal, 22(6), 577-594. Doi: 10.1177/0266242604047411.

World Tourism Organization, UNWTO. (e.d.). Why tourism? Tourism - an economic and social phenomenon. Sótt 31. mars 2016 af http://www2.unwto.org/content/why-tourism 